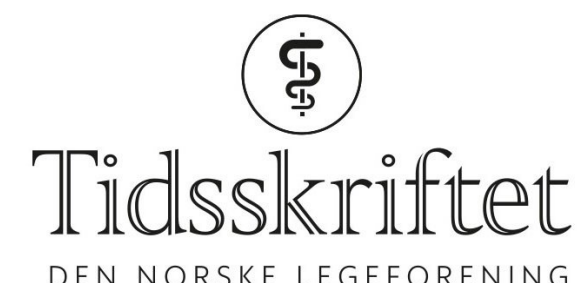

DEN NORSKE LEGEFORENING

\title{
Opioider, makt og misbruk
}

FRA REDAKTØREN

\section{KARI TVEITO}

E-post: kari.tveito@tidsskriftet.no

Kari Tveito er medisinsk redaktør i Tidsskriftet. Hun er lege og ph.d.

Hva er sammenhengen mellom gratis middag og overdosedødsfall?

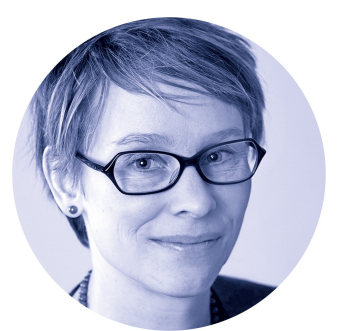

Foto: Einar Nilsen

I 1996 lanserte Purdue Pharma, et av de ledende legemiddelfirmaene i USA, en ny form for oksykodon-OxyContin. Legemidlet frigjorde opioid langsommere enn andre smertestillende medikamenter og skulle derfor være mindre avhengighetsskapende, hevdet firmaet (1).

Opioider er en fellesbetegnelse på morfinlignende preparater eller rusmidler som virker på opioidreseptorer i hjernen (2). Alle virker beroligende og smertedempende og kan gi en rusvirkning. Til tross for svært mangelfull dokumentasjon tillot U.S. Food and Drug Administration (FDA) at en dobbelt så stor dose oksykodon ble brukt i OxyContin som i tilsvarende medikamenter, og at en påskrift om lavt misbrukspotensial fikk stå på forpakningen. Vel 20 år senere har USA fått tilnavnet Opioid Nation og står overfor et folkehelseproblem av enorme proporsjoner (1). Hver dag dør mer enn 130 mennesker av opioidoverdoser, og i 2017 hadde om lag 1,7 millioner amerikanere avhengighetslidelser knyttet til reseptbelagte opioider (3).

De fleste overdosedødsfallene på grunn av opioider skyldes inntak av fentanyl, heroin og kokain (4). Men reseptbelagte opioider er ofte også involvert, og i begynnelsen av opioidkrisen var reseptbelagte medisiner som OxyContin den vanligste årsaken til slike $\mathrm{d} ø \mathrm{~d}$ sfall. For OxyContin, som andre opioider, er avhengighetsskapende. Mange pasienter som begynte å bruke medikamentet, opplevde at de måtte ta stadig høyere doser for å få samme smertestillende effekt. Noen fant ut at tablettene kunne knuses og sniffes eller injiseres og gi en sterk ruseffekt. OxyContin ble raskt "the hottest thing on the street» og mer populært på det illegale markedet enn opioider med kortere virketid. Dette var stikk i strid med hva Purdue Pharma hadde reklamert med - og fortsatte å hevde lenge etter at de første rapportene om overdosedødsfall kom (5). 
Purdue Pharma, eid av den styrtrike Sackler-familien, førte en usedvanlig aggressiv markedskampanje av OxyContin overfor amerikanske leger. Flere og flere leger begynte å forskrive medikamentet til pasientene sine. Samtidig begynte tallet på dødelige opioidrelaterte overdoser å stige. Nylig publiserte JAMA Network Open en studie der man undersøkte om det er en assosiasjon mellom markedsføring, forskrivning og overdoser av opioide medikamenter (4). Resultatene er tankevekkende: I de statene der legemiddelrepresentanter for opioide, smertestillende medikamenter hadde hatt hyppigst kontakt med leger, og leger hadde mottatt flest ytelser i form av måltider, dekning av reisekostnader, honorarer og lignende, var antallet overdosedødsfall høyest ett år senere.

Siden slutten av 1990-årene har det vært en eksplosiv økning i mortalitet blant Amerikas middelaldrende, ikke-latinske, hvite arbeiderklasse. Disse såkalte «deaths of despair», hovedsakelig på grunn av overdoser, alkoholrelaterte sykdommer og selvmord, har blitt knyttet til vanskelige økonomiske og sosiale kår (6). Mot denne bakgrunnen avtegner det seg et bilde av en farmasøytisk industri som kynisk har utnyttet mulighetene i et marked delvis skapt av samfunnsendringer. I et av de siste av en lang rekke søksmål mot Purdue Pharma kom det nylig frem at selskapet blant annet skal ha benyttet seg av konsulentfirmaet McKinsey for å finne ut hvordan de kunne øke salget av OxyContin, motarbeide tiltak for å redusere opioidbruk og «dysse ned emosjonelle meldinger fra mødre til tenåringer som hadde dødd på grunn av medikamentoverdoser» (7).

I Norge hentet 564 ooo voksne ut minst én resept på opioider i 2017 (8). Det tilsvarer en $\emptyset$ kning i bruk på drøyt $9 \%$ siden 2005. Særlig stor har økningen vært for oksykodon, med nærmere en seksdobling i antall brukere. Selv om antall narkotikautløste dødsfall i 2017 var det laveste på ti år, var inntak av morfin, kodein, oksykodon og metadon hyppigere dødsårsaker enn bruk av heroin (9). Noe av økningen i forbruket av sterke opioider kan skyldes en eldre befolkning som oftere trenger smertebehandling. Det er likevel grunn til å være på vakt mot en utvikling etter amerikansk mønster. Heldigvis er forskrivning av opioider strengt regulert og kontrollert av helsemyndighetene. Men hovedansvaret for riktig bruk av opioider ligger hos den enkelte lege. Og vi bør tenke oss om en ekstra gang før vi takker ja til en sponset middag.

\section{LITTERATUR:}

1. Angell M. Opioid Nation. The New York Review of Books 6.12.2018.

https://www.nybooks.com/articles/2018/12/o6/opioid-nation/(12.2.2019).

2. Westin AA, Strøm EJH, Slørdal L. Opiat eller opioid? Tidsskr Nor Legeforen 2011; 131: 1320-1. [CrossRef]

3. National Institute on Drug Abuse. Opioid overdose crisis.

https://www.drugabuse.gov/drugs-abuse/opioids/opioid-overdose-crisis\#five (12.2.2019).

4. Hadland SE, Rivera-Aguirre A, Marshall BDL et al. Association of pharmaceutical industry marketing of opioid products with mortality from opioid-related overdoses. JAMA Netw Open 2019; 2: e1860o7. [PubMed][CrossRef]

5. Meier B. Origins of an epidemic: Purdue Pharma knew its opioids were widely abused. The New York Times 29.5.2018. https://www.nytimes.com/2018/05/29/health/purdue-opioids-oxycontin.html (12.2.2019).

6. Case A, Deaton A. Rising morbidity and mortality in midlife among white non-Hispanic Americans in the 21st century. Proc Natl Acad Sci U S A 2015; 112: 15078-83. [PubMed][CrossRef]

7. Forsythe M, Bogdanich W. McKinsey advised Purdue Pharma how to "turbocharge" opioid sales, lawsuit says. The New York Times 1.2.2019.

https://www.nytimes.com/2019/o2/o1/business/purdue-pharma-mckinsey-oxycontin-opiods.html (12.2.2019).

8. Folkehelseinstituttet. Statistikk fra Reseptregisteret. www.reseptregisteret.no/Prevalens.aspx (12.2.2019). 
9. Folkehelseinstituttet. Narkotikautløste dødsfall 2017.

https://www.fhi.no/nyheter/2018/nakotikautloste-dodsfall-2017/ (12.2.2019).

Publisert: 25. februar 2019. Tidsskr Nor Legeforen. DOI: 10.4045/tidsskr.19.0140

(C) Tidsskrift for Den norske legeforening 2020. Lastet ned fra tidsskriftet.no 